\title{
CONTENTS OF VOLUME 20
}

Blangiewicz, M., T.W. Bolt and W.W. Charemza, Alternative Data for the Dynamic Modelling of the East European Transformation

Swanson, D.A. and D.M. Beck, A New Short-Term County Population Projection Method

Acharya, A. and H.J. Wall, An Evaluation of the United Nations' Human Development Index

Bailey, A.J., Opportunities for Geographic Research with the National Longitudinal Survey of Youth

Belman, D., T.E. Franklin and J.S. Heywood, Comparing Public and Private Earnings Using State Wage Surveys

Stratton, L.S., Reexamining Involuntary Part-Time Employment

Walden, D.C., R. Miller and S.B. Cohen, Comparison of Out-of-Pocket Health Expenditure Estimates from the 1987 National Medical Expenditure Survey and the Consumer Expenditure Survey

O'Connell, M. and L. Miller, Whose Vital Events Are They? The Effect of Immigration on the Estimation of Fertility and Marital History Data from Retrospective Surveys

Cohen, S.B., Guest Editor's Preface

Cohen, S.B. and J.J. Braden, Alternative Options for State Level Estimates in the National Medical Expenditure Survey

Braden, J.J. and S.B. Cohen, An Application of Small Area Estimation Techniques to Derive State Estimates of Health Insurance Coverage from the 1987 NMES

Carlson, B.L., S.B. Cohen and A.E. Johnson, Family Unit Constructs, Dynamics, and Analysis in the Household Component of the NMES

Mathiowetz, N.A. and T.J. Lair, Getting Better? Change or Error in the Measurement of Functional Limitations

Potter, D.E.B. and P.J. Cunningham, An Evaluation of a Method Used to Impute Residence Data

Coomes, P., W. Stober and R. Thalheimer, Measuring the Intrastate Distribution of State Government Funds: A Case Study

Buckmaster, D., E. Saniga and S. Tadesse, Measuring Lobbying Influence Using the Financial Accounting Standards Board Public Record

Master Index Volumes 11-20

Contributors to Articles in Volume 20 